\title{
Penyuluhan Kesehatan untuk Pencegahan dan Risiko Penyakit DBD dalam Manga dan Infografis
}

\section{Health Counseling for Prevention and Risk of DHF Disease in Manga and Infographics}

\author{
Shinta Nasution ${ }^{1}$, Dwi Sadono ${ }^{2}$, Cahyono Tri Wibowo \\ ${ }^{1}$ Bappedalitbang Kabupaten Bogor \\ ${ }^{2}$ Departemen Sains Komunikasi dan Pengembangan Masyarakat, Fakultas Ekologi Manusia, \\ Institut Pertanian Bogor
}

\begin{abstract}
Dengue Hemorrhagic Fever (DHF) is an endemic in tropical areas, such as Indonesia, and at risk of death. The success of health risk counseling needs to be supported by the form of media that is used, especially for Sismantik (Student Monitoring of larvae) as strategic partner of health institution in DHF disease prevention counseling. Visual messages in manga comic and infographic are important to consider as health counseling media for children. The research aimed to: (1) analyze visual media influence and (2) analyze the comparison of manga comic and infographics effectiveness on Sismantik in Cibinong and Bojong Gede Bogor. The study used true experiments method with $2 \times 2$ factorial designs that divided 234 students randomly into four treatment groups that received positive and negative messages and 57 other students as control group. The treatment results proved to be able to give the treatment groups an increased effect on understanding information, risk perception and attitude toward prevention of DHF disease compared to the control group. The most effective visual media to increase risk perceptions and attitudes is the manga comic. However, visual media treatment has not been able to increase the perception of Sismantik negative risk. Both visual media have the same level of effectiveness to increase understanding information.
\end{abstract}

Keywords: DHF disease, health counseling, infographics, manga, visual effect

\begin{abstract}
Demam Berdarah Dengue (DBD) adalah endemik di daerah tropis seperti di Indonesia dan berisiko pada jatuhnya korban jiwa. Keberhasilan penyuluhan risiko kesehatan perlu didukung bentuk media yang digunakan, khususnya bagi Sismantik (Siswa Pemantau Jentik) sebagai mitra strategis instansi kesehatan dalam penyuluhan pencegahan penyakit DBD. Pesan visual dalam komik manga dan infografis penting dipertimbangan sebagai media penyuluhan kesehatan bagi anak-anak. Penelitian ini bertujuan untuk: (1) menganalisis pengaruh media visual (2) menganalisis perbandingan efektifitas komik manga dan infografis pada Sismantik di Cibinong dan Bojong Gede Bogor. Studi menggunakan true experiment dengan desain faktorial 2 x 2 yang membagi 234 siswa secara acak ke dalam empat kelompok perlakuan yang menerima pesan positif dan negatif dan 57 siswa sebagai kelompok kontrol. Perlakuan media visual terbukti mampu memberikan efek berupa peningkatan pemahaman informasi, persepsi risiko dan sikap Sismantik terhadap pencegahan penyakit DBD dibanding kelompok kontrol. Media visual yang paling efektif untuk meningkatkan persepsi risiko dan sikap adalah komik manga. Namun, perlakuan media visual belum mampu meningkatkan persepsi risiko negatif Sismantik. Kedua media visual memiliki tingkat efektifitas yang sama dalam meningkatkan pemahaman informasi.
\end{abstract}

Kata kunci: penyakit DBD, penyuluhan kesehatan, infografis, manga, efek visual

\section{Pendahuluan}

Kesehatan merupakan bagian penting sepanjang kehiduan manusia dan menjadi indikator yang menunjukkan kualitas pertumbuhan pembangunan suatu bangsa dalam kaitannya dengan Indeks Pembangunan Manusia (IPM). Sejalan dengan tujuan SDGs (Sustainable Development Goals) sebagai kelanjutan dari global goals Milenium
Development Goals (MDGs) yang berakhir tahun 2015, maka perlu diupayakan langkah-langkah pencegahan penyakit dalam rangka pencapaian goals point ke-3 yaitu menjamin kesehatan yang baik serta mendorong kesejahteraan hidup. Pertumbuhan penduduk yang cukup tinggi dan berimplikasi pada bertambah luasnya areal pemukiman penduduk mempengaruhi timbulnya berbagai masalah kesehatan yang berkaitan dengan lingkungan tempat 
tinggal, termasuk di antaranya penyakit DBD.

Demam Berdarah Dengue (DBD) merupakan masalah kesehatan yang berjangkit di daerah tropis seperti di Indonesia dan biasanya terjadi pada musim penghujan maupun pancaroba. Wilayah penyebaran penyakit DBD semakin lama semakin meluas, hingga tahun 2014, tercatat penderita penyakit DBD di 34 provinsi di Indonesia sebanyak 71.668 jiwa, dan 641 di antaranya meninggal dunia (PKP Kemenkes RI, 2015). Data Dinas Kesehatan Kabupaten Bogor tahun 2015 menunjukkan jumlah kasus penyakit DBD sebesar 1.313 kasus, dengan rincian penderita tertinggi pada golongan umur 15-44 tahun sebanyak 882 penderita dan golongan umur 5-14 tahun sebanyak 558 penderita (Dinkes Kab. Bogor, 2015). Mengacu pada jumlah total penduduk Kabupaten Bogor tahun 2015 sebesar 5.331.149 jiwa, maka penderita penyakit DBD tertinggi berada pada usia anakanak mengingat jumlah penduduk pada level 5-14 tahun sebesar 1.764 .885 jiwa $(33,1 \%)$ lebih sedikit dibandingkan usia 15-44 tahun sebesar 2.686.549 jiwa (50,39\%). Tiga wilayah tertinggi kasus penyakit DBD di Kabupaten Bogor tahun 2015 ditempati oleh Kecamatan Cibinong sebesar 282 kasus, Kecamatan Bojong Gede sebesar 104 kasus, dan Kecamatan Sukaraja sebesar 90 kasus. Faktor utamanya adalah banyak ditemukannya saluran air yang memang tidak mengalir (seperti got pembuangan) termasuk tempattempat lainnya yang menjadi sarang nyamuk Aedes.

Permasalahan penyakit DBD di Indonesia masih mengalami kendala dan hanya menjadi tanggung jawab pemerintah khususnya petugas kesehatan. Padahal peran serta masyarakat menjadi penunjang utama dalam pengendalian penyakit DBD, mengingat vektor penyakit DBD nyamuk Aedes dan tempat istirahat nyamuk dewasa terdapat di sekitar pemukiman warga baik di dalam maupun di luar rumah tinggal seperti sekolah dan tempat-tempat umum (TTU) lainnya.

Kurangnya partisipasi masyarakat dalam kegiatan Pemberantasan Sarang Nyamuk (PSN) menunjukkan kesadaran dan pemahaman masyarakat terhadap risiko kesehatan akibat penyakit DBD masih rendah. Meskipun sejak akhir September 2016 vaksin penyakit DBD telah ada, namun upaya pencegahan lebih efektif dibandingkan hanya mengandalkan keberadaan vaksin. Satu-satunya cara mencegah penularan penyakit ini adalah memutus rantai penularan melalui PSN dengan memberantas vektor atau nyamuk penularnya (Aedes). Namun, masyarakat baru menyadari bahaya penyakit DBD jika sudah terdapat beberapa korban di wilayahnya dengan melaporkan kepada Dinas Kesehatan setempat. Langkah selanjutnya, dilakukan tindakan fogging (pengasapan) dengan insektisida jenis tertentu, padahal tindakan tersebut tidak akan efektif jika tidak disertai dengan kegiatan PSN dengan Malathion dan penaburan Abate Temephos. Alasan lainnya penanggulangan dengan menggunakan zat kimia (fogging) belum memberikan hasil yang optimal, dalam arti tidak dapat menaikkan ABJ (Angka Bebas Jentik) riil sama atau lebih besar dari 95. Padahal nilai ABJ yang kurang dari 95 berarti virus dengue masih mempunyai peluang menular (Depkes RI, 2009).

PSN dilaksanakan dengan tindakan $3 \mathrm{M}$ (Menutup, Menguras dan Memanfaatkan barang bekas yang masih bernilai) sebagai kegiatan terencana secara terus-menerus dan berkesinambungan. Gerakan ini merupakan kegiatan yang paling efektif untuk mencegah terjadinya penyakit DBD serta mewujudkan kebersihan lingkungan dan perilaku hidup sehat (Kemenkes, 2014).

Penyakit DBD tidaklah berisiko jika dilakukan tindakan pencegahan dengan PSN. Namun, belum optimalnya penyuluhan kesehatan tentang pencegahan DBD oleh instansi kesehatan menyebabkan timbul persepsi bahwa penyakit DBD sangat berisiko. Hal ini senada dengan hasil penelitian Ahmadi dan Sulaiman (2009) bahwa kekhawatiran akan bahaya flu babi disebabkan karena sosialisasi pencegahan flu babi yang belum maksimal dari pemerintah.

Risiko penyakit DBD yang berakibat pada jatuhnya korban jiwa menjadi alasan penting untuk menyediakan dan menyebarkan pesan-pesan yang akurat dengan cepat dan mudah dipahami. Penyuluhan tentang pencegahan penyakit DBD dilakukan di berbagai lokasi, salah satunya adalah lingkungan sekolah. Penyuluhan kesehatan merupakan bagian penting dalam upaya promosi kesehatan (promkes) oleh petugas terkait di lingkungan sekolah sangat efektif sebab anak sekolah merupakan sasaran yang berperan strategis. Jumlahnya sangat banyak yaitu $20 \%$ dari jumlah penduduk Indonesia adalah anak sekolah dan tersebar baik di pedesaan maupun perkotaan (Kemenkes, 2014). Anak sekolah mudah dijangkau dan terorganisasi dengan baik. Selain itu, kelompok anak sekolah menjadi perhatian penting 
karena jumlahnya termasuk ke dalam persentase penderita tertinggi. Notoatmodjo (2005) berpendapat anak sekolah sebagai kelompok yang mudah untuk dibimbing, diarahkan, dan ditanamkan kebiasaankebiasaan baik. Siswa sebagai sasaran penyuluhan kesehatan merupakan aset strategis dalam pencegahan penyakit DBD. Dengan demikian, sektor pendidikan harus menjadi mitra penting instansi kesehatan dalam promosi kesehatan (Jayawardene et al., 2011).

Peran serta anak sekolah sebagai bagian Jumantik yaitu Sismantik (Siswa Pemantau Jentik) dapat digunakan untuk menanamkan perilaku hidup bersih dan sehat (PHBS) pada usia dini melalui penyuluhan kesehatan baik di sekolah maupun di rumah, yang akan digunakan sebagai dasar pemikiran dan perilakunya di masa yang akan datang. Kehadiran Sismantik juga memiliki nilai tambah karena mereka dapat menjadi pemantau jentik di rumah sendiri, sedangkan pemantauan oleh Jumantik harus dilakukan door to door dan tidak semua masyarakat bersedia untuk diperiksa kondisi rumahnya agar bebas jentik. Selain itu, Sismantik juga berperan penting sebagai kader penyuluhan informasi risiko dan pencegahan penyakit DBD khususnya di sekolah. Oleh karena itu, pendekatan komunikasi risiko kesehatan perlu dipertimbangkan agar informasi dalam penyuluhan sesuai dengan tujuan yang diharapkan.

Informasi statistik (angka) dalam komunikasi risiko kesehatan sering digunakan untuk mendukung dan memperjelas pesan. Namun, pesan visual lebih mudah dipahami oleh masyarakat dibandingkan dengan data berupa angka (Garcia-Retamero dan Mandeep, 2011; Politi, 2012). Sejumlah penelitian mendukung keberhasilan pesan visual dalam komunikasi kesehatan, yaitu memperjelas informasi yang sulit, memperluas pengetahuan, meningkatkan perhatian dan pemahaman (King et al., 2014), mengingat kembali informasi kesehatan (Mcwhirter dan Hoffman-Goetz, 2014) dan format efektif dalam informasi risiko kesehatan (Dur et al., 2014; Stone et al., 2015). Berdasarkan penelitian tersebut, visualisasi pesan menjadi metode yang bermanfaat untuk menampilkan informasi risiko kesehatan yang rumit dan ilmiah dengan cara yang mudah dalam penyampaiannya.

Pesan visual tentunya harus dikemas dalam media yang tepat. Notoatmodjo (2005: 290-291) berpendapat melalui media komunikasi, sasaran dapat meningkat pengetahuannya yang akhirnya dapat merubah ke arah perilaku kesehatan positif. Oleh karena itu, petugas kesehatan perlu mempertimbangkan media penyuluhan kesehatan yang tepat dalam menunjang keberhasilan komunikasi risiko kesehatan DBD, khususnya bagi anak-anak sebagai Sismantik. Fakta di lapangan menunjukkan penyuluhan kesehatan masih bersifat statis (satu arah) melalui metode ceramah tanpa menggunakan media. Akibatnya, sasaran kurang merasa tertarik terhadap informasi yang disampaikan. Meskipun terdapat juga penyuluhan kesehatan yang menggunakan media, tetapi tidak memperhatikan kesesuaian media dengan usia sasaran, terutama siswa Sekolah Dasar. Saat ini, leafleat masih menjadi media andalan dalam penyuluhan kesehatan.

Hasil penelitian menunjukkan komik untuk kepentingan praktis lebih baik diarahkan bagi anakanak, karena lebih menarik bagi pembaca usia muda (Branscum dan Sharma, 2009). Sifat komik yang menyenangkan sehingga anak-anak dapat merespon pesan dengan baik, menarik perhatian bagi mereka yang enggan membaca terlebih lagi bagi yang senang membaca (Serchay, 2008; Viadero, 2009). Sayangnya, komik belum dimanfaatkan dengan baik dalam intervensi promosi kesehatan, padahal merupakan alat pendidikan yang menjanjikan, terutama di kalangan anak-anak (Branscum dan Sharma, 2009).

Hal yang menarik dari penelitian sebelumnya adalah dari sepuluh penelitian tentang komik manga kesehatan (Wakane et al., 2007; Leung, 2010; Leung et al, 2014; Matsuoka et al., 2011; Mutonyi dan Kendrick, 2011; Sakamoto et al., 2014; Ohyama et al., 2015; Furuno dan Sasajima, 2015; TekleHaimanot et al., 2016), hanya ada 4 penelitian tentang efek visual terhadap pemahaman informasi risiko kesehatan (Sakamoto et al., 2014; Ohyama et al., 2015; Furuno dan Sasajima, 2015; Tekle-Haimanot et al., 2016), tetapi belum meneliti lebih lanjut tentang pengaruh manga melalui pendekatan komunikasi risiko kesehatan. Pentingnya pendekatan komunikasi risiko dua arah telah dibuktikan dalam penelitian sebelumnya bagi perubahan perilaku kesehatan positif.

Selama ini, penelitian tentang kekuatan visual dengan pendekatan komunikasi risiko kesehatan lebih banyak menggunakan grafis numerik (grafik, icon array, tabel) sebagai penguat informasi. Cummings (2013) merekomendasikan pentingnya dilakukan penelitian eksperimental terhadap 
kekuatan visual, selanjutnya mengkaji pengaruhnya terhadap pemahaman informasi, pemrosesan informasi, dan bagaimana individu menilai pesan risiko yang mungkin mengakibatkan perubahan perilaku kesehatan. Dari sembilan penelitian tentang visualisasi grafis dengan pendekatan komunikasi risiko (King et al., 2014; Ancker et al., 2006; Zikmund-Fisher et al., 2008; Garcia-Retamero dan Galesic, 2010; Wong et al., 2012; Garcia-Retamero dan Mandeep, 2011; Politi, 2012; Miller dan Barnett, 2010; Ru dan Ming, 2014) hanya dua penelitian yang menggunakan infografis (Miller dan Barnett, 2010; $\mathrm{Ru}$ dan Ming, 2014) dalam menyampaikan pesan kesehatan. Selain itu, keseluruhan media tersebut tidak ditujukan bagi anak-anak.

Berdasarkan penjelasan di atas, maka penting dilakukan penelitian dengan pendekatan komunikasi risikokesehatan, yangmenggunakan komikmanga dan infografis statis (cetakan) sebagai media penyuluhan dengan pendekatan tersebut untuk mengetahui pengaruhnya terhadap pemahaman informasi, persepsi risiko dan sikap terhadap pencegahan DBD serta keefektifannya sebagai media informasi risiko dan pencegahan DBD bagi anak-anak. Kedua media tetap menggunakan unsur visual (kartun dan grafis numerik) yang sama dalam mensosialisasikan pesan kesehatan. Gambar kartun yang dipilih menggunakan karakter yang diminati untuk menghasilkan efek sikap kesehatan positif (Branscum dan Sharma, 2009; Mayo, 2011). Berdasarkan beberapa penelitian tentang pentingnya unsur cerita dalam media (Quintiliani dan Carbone, 2005; Hecht dan MillerDay, 2007; Edgar dan Volkman, 2012), maka cerita berdasarkan fakta digunakan dalam desain kedua media Berbagi cerita dapat menambah kredibilitas dan otentisitas pesan kesehatan (Kreuter et al., 2007). Berdasarkan hal tersebut tujuan penelitian ini adalah: (1) menganalisis pengaruh media visual dan; (2) menganalisis perbandingan efektifitas manga dan infografis sebagai media penyuluhan bagi Sismantik di Kecamatan Cibinong dan Bojong Gede Kabupaten Bogor.

\section{Metode Penelitian}

Penelitian dilaksanakan di dua kecamatan yang menjadi endemis DBD tertinggi di Kabupaten Bogor yaitu Kecamatan Cibinong dan Bojong Gede. Kabupaten Bogor sendiri merupakan wilayah dengan kasus DBD cukup tinggi di Jawa Barat. Responden berasal dari siswa kelas V dan VI Madrasah Ibtidaiyah (MI) Al Huda Cibinong dan Nurul Qolbi Bojong Gede. Sekolah tersebut dipilih karena berada pada desa/kelurahan dengan kasus DBD tertinggi, sedangkan tingkat keterlibatan PHBS-nya masih rendah. Selain itu, Sismantik juga berada pada rentang kelas tersebut.

Populasi total saat dilaksanakan eksperimen berjumlah 291 orang, yang terdiri dari 148 siswa Madrasah Ibtidaiyah Al Huda Kecamatan Cibinong dan 143 siswa Madrasah Ibtidaiyah Nurul Qolbi Kecamatan Bojong Gede. Madrasah Ibtidaiyah Al Huda terdiri dari 73 orang siswa kelas V dan 75 orang siswa kelas VI, sementara Madrasah Ibtidaiyah Nurul Qolbi terdiri dari 70 orang siswa kelas V dan 73 orang siswa kelas VI. Jumlah tersebut dibagi menjadi kelompok perlakuan dengan jumlah total 234 orang dan kelompok kontrol 57 orang dengan prosedur acak.

Tabel 1. Rancangan Kelompok-Kontrol pre-test dan post-test

Kelas $\quad \begin{gathered}\text { Observasi } \\ 1 \\ \text { (Pre-test) }\end{gathered}$ Perlakuan $\begin{gathered}\text { Observasi 2 } \\ \text { (Post-test) }\end{gathered}$

\begin{tabular}{llll}
\hline Kelompok A & $\mathrm{O}_{1}$ & $\mathrm{X}$ & $\mathrm{O}_{2}$ \\
Kelompok B & $\mathrm{O}_{1}$ & $\mathrm{X}$ & $\mathrm{O}_{2}$ \\
Kelompok C & $\mathrm{O}_{1}$ & $\mathrm{X}$ & $\mathrm{O}_{2}$ \\
Kelompok D & $\mathrm{O}_{1}$ & $\mathrm{X}$ & $\mathrm{O}_{2}$ \\
Kelompok E & $\mathrm{O}_{1}$ & & $\mathrm{O}_{2}$ \\
\hline
\end{tabular}

Keterangan: $\mathrm{O}=$ pengamatan; $\mathrm{X}=$ perlakuan

Penelitian ini dirancang berdasarkan metode eksperimen. Stimulus eksperimen yang digunakan berupa media visual manga dan infografis statis. Studi menggunakan metode true experiment dengan desain faktorial $2 \times 2$ (tabel 2) dan menggunakan pretest posttest control group design yang membagi responden secara acak ke dalam empat kelompok perlakuan yang memperoleh media visual dan satu kelompok kontrol tanpa media visual. Kelima kelompok tersebut sama-sama dilakukan pre-test dan post-test.

Media visual sebagai peubah bebas yang 
terdiri dari 2 faktor perlakuan, yaitu jenis media visual (manga dan infografis statis) dan isi pesan (positif dan negatif). Pesan positif berupa manfaat pencegahan penyakit $\mathrm{DBD} /$ gerakan $3 \mathrm{M}$ Plus dan pesan negatif berupa risiko DBD. Dua peubah bebas aktif yang diamati masing-masing terdiri dari dua perlakuan, sehingga diperoleh empat kombinasi antara lain manga manfaat positif (kelompok A), manga risiko penyakit (kelompok C), infografis statis manfaat positif (kelompok B), dan infografis statis negatif (kelompok D). Matriks kombinasi perlakuan dapat dilihat pada Tabel 2.

Tabel 2. Matriks Desain Faktorial 2 x 2 true eksperiment (pre-test post-test control group design) dengan Faktor Jenis Media dan Isi Pesan

\begin{tabular}{cccl}
\hline & & \multicolumn{2}{c}{ Isi Pesan } \\
\cline { 3 - 4 } No & $\begin{array}{c}\text { Jenis } \\
\text { Media }\end{array}$ & $\begin{array}{c}\text { Manfaat } \\
\text { Positif } \\
\text { Pencegahan } \\
\text { DBD }\end{array}$ & \multicolumn{1}{c}{$\begin{array}{c}\text { Risiko } \\
\text { Penyakit DBD }\end{array}$} \\
\hline \multirow{2}{*}{1} & Manga & $\begin{array}{l}\text { Manga- } \\
\text { Manfaat Positif } \\
\text { (n=60) }\end{array}$ & $\begin{array}{l}\text { Manga-Risiko } \\
\text { Penyakit } \\
\text { (n=57) }\end{array}$ \\
& & $\begin{array}{l}\text { Infografis- } \\
\text { Infografis } \\
\text { Statis }\end{array}$ & $\begin{array}{l}\text { Infografis- } \\
\text { Risiko }\end{array}$ \\
& & (n=60) & $\begin{array}{l}\text { Penyakit } \\
\text { (n=57) }\end{array}$ \\
\hline
\end{tabular}

Data yang dikumpulkan dalam penelitian ini adalah data primer dan data sekunder. Data primer yang diperoleh secara kuantitatif diperkuat oleh wawancara dengan responden dari masing-masing kelompok perlakuan sebanyak dua orang. Tujuannya untuk menggali informasi spesifik yang diperlukan dalam mendukung hasil analisis data statistik. Selain itu, dilakukan ujicoba efektivitas rancangan media melalui kuesioner yang ditujukan kepada ahli media sebagai praktisi di bidang desain media dan ahli materi dari akademisi Pemberantasan Penyakit Menular (P2M).

Bahan acuan desain media visual diperoleh dari hasil penelitian sebelumnya dan data sekunder lain yang berisi bentuk visual yang tepat bagi komunikasi risiko termasuk karakter yang sedang digemari anak-anak saat ini. Data sekunder lainnya diperoleh dari lembaga terkait. Selanjutnya, data dianalisis dengan statistik inferensial yaitu: paired sample t test; ANOVA dan; Duncan's multiple range test. Data kualitatif digunakan untuk memberikan penjelasan terhadap data kuantitatif.

\section{Hasil dan Pembahasan}

\section{Pengaruh Media Visual}

Pemahaman informasi awal Sismantik sebelum dilakukan eksperimen secara keseluruhan sudah cukup baik. Hasil wawancara menunjukkan informasi awal Sismantik tentang penyakit DBD di kedua lokasi sebagian telah diperoleh dari penyuluhan kesehatan yang disampaikan guru di sekolah dan media massa (khusus MI Al Huda Cibinong), sedangkan dari intansi kesehatan terkait belum dilakukan. Sumber informasi Sismantik yang lebih luas tentang penyakit DBD di MI Al Huda Cibinong menyebabkan pemahaman informasi awal mereka lebih tinggi dibandingkan MI Nurul Qolbi Bojong Gede. Hal ini dapat dimaklumi mengingat karakteristik Kecamatan Cibinong (perkotaan) yang memudahkan akses informasi dan komunikasi jika dibandingkan Kecamatan Bojong Gede (pedesaan) sehingga mereka bukan hanya mendapat informasi hanya melalui penyuluhan tetapi juga iklan persuasif cegah DBD melalui media massa.

Catatan hasil penelitian penting di sini adalah informasi awal yang dimiliki Sismantik hanya seputar vektor penular penyakit DBD, sedangkan langkah pencegahan secara rinci dan peran penting Sismantik belum diperoleh. Implikasinya adalah rendahnya skor pemahaman awal Sismantik pada pertanyaan seputar gerakan 3M Plus dan peran Sismantik. Selain itu, fakta bahwa mayoritas penyuluhan kesehatan yang terintegrasi dengan konsep pendidikan hanya berfokus pada vektor Aedes juga mempengaruhi rendahnya skor pemahaman awal Sismantik pada pertanyaan seputar penyebab penyakit DBD. Sebagian besar Sismantik menganggap penyebab penyakit DBD adalah nyamuk, sementara hanya sebagian kecil yang bisa menjawab virus sebagai penyebabnya. Kekeliruan tersebut akan terus berlanjut jika tidak dilaksanakan penyuluhan dengan informasi yang jelas. Data juga menunjukkan mayoritas Sismantik mengetahui setidaknya satu gejala penyakit DBD. Kemampuan Sismantik untuk mengenali gejala penyakit DBD penting sebagai langkah mencari 
pengobatan awal.

Hasil uji eksperimen menemukan terdapat perbedaan peningkatan pemahaman informasi antara kelompok kontrol dengan kelompok perlakuan pada Sismantik baik secara keseluruhan maupun per lokasi sekolah (Tabel 3). Data pada kelompok perlakuan menunjukkan terjadi peningkatan pemahaman Sismantik dengannilai mean lebih tinggi dibandingkan sebelum diberi perlakuan. Selanjutnya, peningkatan pemahaman Sismantik pada kelompok kontrol terjadi sangat kecil yaitu rata-rata di bawah 1.00. Studi juga menunjukkan perubahan nilai mean pemahaman informasi Sismantik pada kelompok perlakuan di MI Nurul Qolbi Bojong Gede lebih tinggi dibandingkan MI Al Huda Cibinong yaitu masing-masing 7.13 dan 10.51. Namun, jika dilihat dari nilai mean hasil post-test menunjukkan angka yang relatif tidak jauh berbeda. Hal ini disebabkan Sismantik kelompok perlakuan di MI Nurul Qolbi memiliki ketertarikan lebih pada media visual saat dilaksanakannya eksperimen sehingga memperhatikan secara seksama isi pesan yang disampaikan media tersebut. Responden MI Nurul Qolbi yang berada di pedesaan (Bojong Gede) memiliki karakteristik masyarakat yang berempati dan menghargai informasi yang disampaikan oleh pihak lain, terlebih jika menyangkut kepentingan masyarakat.

Perubahan nilai mean pada pemahaman informasi (Tabel 3) diperoleh dari kenaikan skor jawaban pada pertanyaan penyebab DBD, perilaku nyamuk Aedes dan gerakan 3M Plus. Fakta di lapangan, sebagian Sismantik telah melaksanakan beberapa bagian gerakan 3M Plus, tetapi mereka tidak mengetahui istilah dari aktivitas tersebut dan baru diketahui dari media visual. Peningkatan pemahaman informasi tentang perilaku nyamuk Aedes penting mengingat beberapa perilaku di masyarakat terkait upaya pencegahan DBD tidak efektif. Contohnya

Tabel 3. Nilai Mean dan Paired Sample t-test Peubah Efek Media Visual pada Sismantik

\begin{tabular}{|c|c|c|c|c|c|c|c|c|c|c|c|c|}
\hline \multirow{4}{*}{ Tipe Kelompok } & \multicolumn{12}{|c|}{ Efek Media Visual } \\
\hline & \multicolumn{4}{|c|}{ Pemahaman Informasi } & \multicolumn{4}{|c|}{ Persepsi Risiko } & \multicolumn{4}{|c|}{ Sikap } \\
\hline & \multicolumn{2}{|c|}{ Mean } & \multirow{2}{*}{$\begin{array}{c}\text { Se- } \\
\text { lisih } \\
\end{array}$} & \multirow{2}{*}{$\begin{array}{c}\text { paired } \\
\text { t-test }\end{array}$} & \multicolumn{2}{|c|}{ Mean } & \multirow{2}{*}{$\begin{array}{c}\text { Se- } \\
\text { lisih } \\
\end{array}$} & \multirow{2}{*}{$\begin{array}{c}\text { paired } \\
t \text {-test }\end{array}$} & \multicolumn{2}{|c|}{ Mean } & \multirow{2}{*}{$\begin{array}{c}\text { Se- } \\
\text { lisih } \\
\end{array}$} & \multirow{2}{*}{$\begin{array}{c}\text { paired } \\
\text { t-test }\end{array}$} \\
\hline & Pre & Post & & & Pre & Post & & & Pre & Post & & \\
\hline \multicolumn{13}{|l|}{$\begin{array}{l}\text { Al Huda } \\
\text { Cibinong } \\
\text { Kelompok } \\
\text { Perlakuan }\end{array}$} \\
\hline Manga $+(n=30)$ & & 27.27 & 5.74 & $.000 *$ & 34.92 & 39.93 & 5.01 & $.000 *$ & 32.97 & 42.07 & 9.10 & $.000^{*}$ \\
\hline Manga - $(n=30)$ & 20.33 & 28.00 & 7.67 & $.000 *$ & 24.20 & 29.50 & 5.30 & $.000 *$ & 34.77 & 38.87 & 2.43 & $.000 *$ \\
\hline Intogratis + & 22.13 & 28.00 & 5.87 & $.000 *$ & 27.87 & 32.87 & 5.00 & $.000^{*}$ & 34.33 & 38.00 & 4.06 & $.003 *$ \\
\hline Infografis - & 19.07 & 28.43 & 9.36 & $.000 *$ & 26.57 & 28.18 & 1.61 & $.029 *$ & 33.57 & 39.26 & 5.71 & $.000 *$ \\
\hline $\begin{array}{l}(n=28)(n=118) \\
\text { Total }(n=118) \\
\text { Kontrol }(n=30) \\
\text { Nurul Qolbi }\end{array}$ & $\begin{array}{l}20.79 \\
22.33\end{array}$ & $\begin{array}{l}27.92 \\
22.60\end{array}$ & $\begin{array}{l}7.13 \\
0.27\end{array}$ & $\begin{array}{l}000^{*} \\
.514^{\mathrm{tn}}\end{array}$ & $\begin{array}{l}26.64 \\
31.33\end{array}$ & $\begin{array}{l}31.96 \\
31.47\end{array}$ & $\begin{array}{l}\mathbf{5 . 3 3} \\
0.14\end{array}$ & $\begin{array}{l}000^{*} \\
.211^{\mathrm{tn}}\end{array}$ & $\begin{array}{l}33.89 \\
32.17\end{array}$ & $\begin{array}{l}39.24 \\
32.43\end{array}$ & $\begin{array}{l}5.32 \\
0.26\end{array}$ & $\begin{array}{l}000^{*} \\
.340^{\mathrm{tn}}\end{array}$ \\
\hline \multicolumn{13}{|l|}{$\begin{array}{l}\text { Bj.Gd } \\
\text { Kelompok }\end{array}$} \\
\hline $\begin{array}{l}\text { Perlakuan } \\
\text { Manga }+(n=30) \\
\text { Manga - }(n=27)\end{array}$ & $\begin{array}{l}15.40 \\
17.15\end{array}$ & $\begin{array}{l}26.07 \\
26.59\end{array}$ & $\begin{array}{l}10.67 \\
9.44\end{array}$ & $\begin{array}{l}.000^{*} \\
.000^{*}\end{array}$ & $\begin{array}{l}27.57 \\
34.70\end{array}$ & $\begin{array}{l}30.57 \\
37.30\end{array}$ & $\begin{array}{l}3.00 \\
2.60\end{array}$ & $\begin{array}{l}.000^{*} \\
.000^{*}\end{array}$ & $\begin{array}{l}28.80 \\
32.52\end{array}$ & $\begin{array}{l}41.57 \\
39.56\end{array}$ & $\begin{array}{l}12.77 \\
7.04\end{array}$ & $.000 *$ \\
\hline $\begin{array}{l}\text { Infografist } \\
(n=30)\end{array}$ & 19.07 & 29.40 & 10.33 & $.000^{*}$ & 30.50 & 32.17 & 1.67 & $.025^{*}$ & 32.13 & 40.43 & 8.30 & $.000^{*}$ \\
\hline $\begin{array}{l}\text { Infografis - } \\
(\mathrm{n}=29)\end{array}$ & 15.31 & 28.83 & 13.52 & $.000 *$ & 30.82 & 33.07 & 2.25 & $.000^{*}$ & 32.31 & 39.45 & 7.14 & $.000^{*}$ \\
\hline $\begin{array}{l}\text { Total }(n=116) \\
\text { Kontrol }(n=27) \\
\text { Kedua Lokasi } \\
\text { Kelompok }\end{array}$ & $\begin{array}{l}16.73 \\
15.93\end{array}$ & $\begin{array}{l}27.24 \\
16.00\end{array}$ & $\begin{array}{l}\mathbf{1 0 . 5 1} \\
0.07\end{array}$ & $\begin{array}{l}000^{*} \\
.802^{\text {th }}\end{array}$ & 30.29 & $\begin{array}{l}33.17 \\
26.96\end{array}$ & $\begin{array}{l}\mathbf{2 . 8 8} \\
-0.30\end{array}$ & $\begin{array}{l}000^{*} \\
.285^{\text {th }}\end{array}$ & $\begin{array}{l}31.41 \\
27.56\end{array}$ & $\begin{array}{l}40.02 \\
27.44\end{array}$ & $\begin{array}{l}\mathbf{8 . 6 1} \\
-0.12\end{array}$ & $\begin{array}{l}000^{*} \\
.502^{\text {th }}\end{array}$ \\
\hline $\begin{array}{l}\text { Perlakuan } \\
\text { Manga }+(n=60) \\
\text { Manga }-(n=57)\end{array}$ & $\begin{array}{l}18.47 \\
18.82\end{array}$ & 26.67 & $\begin{array}{l}8.20 \\
8.51\end{array}$ & $\begin{array}{l}.000^{*} \\
.000 *\end{array}$ & $\begin{array}{l}28.14 \\
29.18\end{array}$ & $\begin{array}{l}33.82 \\
33.19\end{array}$ & $\begin{array}{l}6.08 \\
5.05\end{array}$ & $\begin{array}{l}.000^{*} \\
.000^{*}\end{array}$ & $\begin{array}{l}30.88 \\
33.70\end{array}$ & $\begin{array}{l}41.90 \\
38.32\end{array}$ & $\begin{array}{l}10.93 \\
4.61\end{array}$ & $.000 *$ \\
\hline $\begin{array}{l}\text { Infografist } \\
(n=60)\end{array}$ & 20.60 & 28.70 & 8.10 & $.003^{*}$ & 28.74 & 32.52 & 3.33 & $.003^{*}$ & 33.23 & 39.42 & 6.18 & $.000 *$ \\
\hline $\begin{array}{l}\text { Infografis - } \\
(\mathrm{n}=57)\end{array}$ & 17.16 & 27.61 & 10.46 & $.000 *$ & 28.45 & 30.66 & 1.93 & $.000^{*}$ & 32.93 & 38.84 & 5.91 & $.000 *$ \\
\hline Total $(\mathrm{n}=234)$ & 18.78 & 27.58 & 8.80 & $000 *$ & 29.40 & 32.56 & 4.12 & $000^{*}$ & 32.66 & 39.62 & 6.95 & $000 *$ \\
\hline Kontrol $(\mathrm{n}=57)$ & 19.30 & 19.47 & 0.18 & $.489^{\text {tn }}$ & 28.14 & 29.33 & -0.07 & $.621^{\mathrm{tn}}$ & 29.98 & 30.07 & 0.09 & $.596^{\mathrm{tn}}$ \\
\hline
\end{tabular}

Keterangan:*) pengaruh signifikan; $\left.{ }^{\text {tn }}\right)$ tidak berbeda nyata 
pemasangan kelambu atau obat nyamuk untuk mencegah gigitan nyamuk biasanya dilakukan di malam hari, padahal nyamuk Aedes menggigit di siang hari dan puncaknya di pagi dan sore hari. Dengan demikian penting dilakukan penyuluhan dengan media yang tepat untuk mengatasi kekeliruan tersebut agar tindakan pencegahan penyakit DBD dapat dilaksanakan dengan efektif.

Kelompok perlakuan yang memiliki perubahan skor dan nilai mean paling tinggi setelah diberikan media visual adalah infografis risiko penyakit (Tabel 3). Hasil wawancara menunjukkan Sismantik lebih cepat menangkap informasi yang diberikan infografis karena informasi yang dimuat singkat dan jelas dengan disertai grafis yang mendukung. Oleh karena itu, infografis tepat dijadikan media penyuluhan kesehatan secara cepat terutama pada saat terjadi risiko.

Persepsi awal di MI Nurul Qolbi Bojong Gede lebih banyak dipengaruhi oleh faktor lingkungan baik keluarga dan masyarakat. Berbeda dengan MI Al Huda Cibinong, persepsi mereka lebih banyak dipengaruhi faktor informasi dari media massa dan teman sebaya (peer group). Hal ini dapat dipahami mengingat anak-anak di wilayah Cibinong sebagai daerah perkotaan lebih banyak berinteraksi dan menghabiskan waktu dengan selain keluarga karena kesibukan aktivitas keseharian. Kondisi tersebut sesuai dengan penelitian Rahayu dan Wigna (2010) yang menyatakan bahwa perbedaan waktu mempengaruhi persepsi antara mahasiswa laki-laki dan perempuan dalam lingkungan keluarga, sekolah dan masyarakat. Mahasiswa perempuan lebih banyak menghabiskan waktu mereka bersama dengan ibu mereka di lingkungan keluarga sedangkan mahasiswa laki-laki lebih banyak melakukan interaksi dengan guru di sekolah dan teman sebaya (peer group) yang kemudian mempengaruhi persepsi mereka.

Pengaruh informasi media massa terhadap Sismantik di MI Al Huda Cibinong berkontribusi dalam pembentukan sifat positif Sismantik yang menganggap penyakit DBD tidak terlalu berisiko dalam persepsi awal. Berdasarkan hasil wawancara dengan Sismantik di MI Al Huda Cibinong dapat diketahui bahwa penyakit yang dianggap berbahaya bukan DBD tetapi kanker dan jantung. Informasi tersebut diperoleh dari media massa seperti televisi dan internet yang banyak memberitakan kasus kematian akibat kedua penyakit tersebut. Namun, lingkungan keluarga dan masyarakat justru lebih berpengaruh pada pembentukan persepsi Sismantik di MI Nurul Qolbi Bojong Gede. Fakta lapangan menunjukkan Sismantik di MI Nurul Qolbi Bojong Gede mengganggap penyakit DBD tidak terlalu berisiko karena menurut persepsi mereka penyakit ini bisa disembuhkan dan jarang menimbulkan kematian di lingkungan tempat tinggal mereka. Selain itu, persepsi positif juga dipengaruhi oleh pengalaman positif tentang kesembuhan pasien di kedua lokasi. Hasil kuesioner menunjukkan hanya sebagian kecil yang mengalami komplikasi penyakit akibat DBD.

Kehadiran persepsi negatif bahwa DBD berisiko pada sebagian Sismantik disebabkan informasi yang diterima bahwa Kecamatan Cibinong dan Bojong Gede merupakan wilayah endemis penyakit DBD. Persepsi negatif juga muncul karena mereka berada pada usia rentan/anak-anak sehingga berisiko terkena penyakit DBD. Namun, mereka meyakini upaya menjaga kebersihan diri dan lingkungan dapat mengurangi risiko akibat penyakit DBD. Oleh karena itu, penting peranan penyuluhan tentang pencegahan penyakit DBD dengan menggunakan media yang sesuai sasaran.

Perubahan persepsi akhir risiko yang signifikan dari kelompok perlakuan disebabkan isi pesan yang terdapat pada media visual mempengaruhi cara pandang Sismantik. Hasil wawancara dengan Sismantik di kedua lokasi dapat diperoleh informasi bahwa setelah membaca manga, Sismantik yakin gerakan 3M Plus bisa mengurangi risiko penyakit DBD. Bahkan, beberapa Sismantik yang telah melaksanakan gerakan 3M Plus sebelumnya, setelah membaca media visual semakin bertambah yakin bahwa penyakit DBD tidak berbahaya asalkan dilakukan tindakan pencegahan. Namun, sebagian Sismantik masih merasa khawatir terkena penyakit DBD karena faktor usia mereka yang berada pada kategori rentan. Hal yang menarik dari data persepsi akhir di kedua lokasi tersebut adalah perubahan signifikan lebih terlihat pada persepsi positif dibandingkan negatif. Penyebabnya adalah sebagian besar Sismantik menilai penyakit DBD tidak terlalu berbahaya dan karenanya tidak memberikan perhatian serius. Pelaksanaan gerakan $3 \mathrm{M}$ yang sebelumnya telah dilakukan semata-mata hanya karena anjuran dan kebiasaan di lingkungan keluarga dan masyarakat dan bukan karena adanya anggapan penyakit DBD sebagai penyakit yang berisiko. 
Mengacu pada paradigma psikometri Slovic, karakteristik risiko penyakit DBD dan upaya pencegahannya tergolong ke dalam lower familiarity/ lower dread. Dalam konteks tersebut, masyarakat memandang penyakit DBD berisiko rendah, tidak segera mengancam kehidupan atau menyebabkan bahaya serius. Namun, faktanya dalam beberapa kasus persepsi individu terhadap risiko justru lebih besar dari risiko yang sebenarnya (Sheppard et al. 2012). Alasan tersebut yang menjadikan persepsi masih dalam kategori positif. Pentingnya peranan penyuluhan kesehatan untuk mengatasi kekeliruan bahwa penyakit DBD harus dicegah sebelum jatuh korban jiwa, dan mengeliminasi kekeliruan bahwa upaya pencegahannya dinilai masih belum perlu dilakukan pada masa sebelum terjadi kasus DBD di lingkungannya.

Berdasarkan Tabel 3 dapat diketahui media yang paling efektif dalam perubahan persepsi baik negatif maupun positif adalah manga. Jika dilihat per lokasi sekolah, maka manga risiko penyakit memiliki nilai mean paling tinggi dibandingkan dengan infografis dalam meningkatkan persepsi risiko negatif. Selanjutnya, jika dilihat dari data di kedua lokasi maka manga manfaat positif yang menunjukkan nilai mean paling tinggi dibandingkan media lainnya. Hasil wawancara diperoleh informasi bahwa unsur cerita (naratif) dalam manga mengubah persepsi mereka bahwa penyakit DBD tidaklah berisiko jika dilakukan pencegahan. Isi pesan disertai karakter yang menarik semakin memperkuat persepsi positif mereka tentang penyakit DBD. Selain itu, manga yang relatif belum familiar di kalangan Sismantik menimbulkan rasa ketertarikan. Secara psikologis persepsi anak dapat diubah melalui media dengan unsur pengulangan, sesuatu yang baru (novelty), dan menarik perhatian (Notoatmodjo, 2010).

Sikap awal tertinggi Sismantik di MI Al Huda Cibinong terdapat pada pernyataan upaya menjaga kesehatan diri, sedangkan di MI Nurul Qolbi Bojong Gede terdapat pada sikap persetujuan penggunaan abate sebagai pembasmi jentik. Hasil wawancara menunjukkan Sismantik cukup familiar dengan abate karena terbiasa menggunakannya terutama ketika musim hujan tiba. Biasanya abate ini diperoleh dari petugas yang menawarkan ke lingkungan tempat tinggal mereka. Selanjutnya, sikap awal terendah Sismantik baik di MIAl Huda Cibinong dan MI Nurul Qolbi Bojong Gede terdapat pada upaya pencegahan penyakit DBD dengan gerakan 3M Plus. Penyebabnya informasi tentang gerakan 3M Plus belum banyak diketahui Sismantik terutama pada kompenen Plus. Contohnya tentang penggunaan ikan pemakan jentik untuk membasmi jentik vektor DBD, sebagian Sismantik belum mengetahui manfaatnya. Hasil wawancara di kedua lokasi menunjukkan sikap awal Sismantik dibentuk sebagian besar oleh lingkungan keluarga dan sekolah. Penyuluhan kesehatan tentang pentingnya kebersihan diri dan lingkungan sudah sejak dini ditanamankan melalui keluarga, sedangkan sikap pencegahan secara umum terhadap penyakit DBD diperoleh melalui penyuluhan kesehatan yang disampaikan guru di sekolah.

Berdasarkan hasil studi dapat diketahui skor tertinggi dari sikap akhir Sismantik terdapat pada persetujuan upaya menjaga kesehatan diri sebagai langkah penting mencegah penyakit DBD. Sikap ini diperoleh dari media visual yang memberikan informasi penyuluhan tentang pentingnya menjaga kesehatan diri seperti makan makanan yang bergizi agar kekebalan tubuh meningkat, sehingga virus penyakit DBD tidak mampu bertahan.

Hal yang menarik dari data perubahan sikap adalah skor perubahan sikap pada Sismantik di MI Nurul Qolbi Bojong Gede lebih tinggi dibandingkan di MI Al Huda Cibinong meskipun skor akhir relatif tidak jauh berbeda. Terlihat antusias Sismantik di MI Nurul Qolbi Bojong Gede dalam memberikan respon lebih terhadap media visual selama proses eksperimen berlangsung. Penyebabnya adalah karakteristik wilayah yang mempengaruhi karakteristik individu. Anak-anak di pedesaan (Bojong Gede) lebih memiliki sikap simpati, empati dan menghargai yang diperoleh dari hasil sosialisasi nilai-nilai di keluarga dan lingkungan masyarakat. Karakteristik tersebut akan membentuk sikap lebih menghargai ajakan positif. Sementara anak-anak di perkotaan (Cibinong) lebih bersikap apatis yang disebabkan pengaruh lingkungan yang serba cepat. Akibatnya sikap menghargai kurang dibudayakan dalam diri individu.

Berdasarkan data di kedua lokasi (Cibinong dan Bojong Gede) di atas, dapat diketahui bahwa terdapat perbedaan nyata $(p$-value $<0.05)$ pada kelompok perlakuan sebelum dan setelah diberi media visual berupa peningkatan pemahaman informasi, persepsi risiko dan sikap terhadap pencegahan penyakit DBD. Sebaliknya pada kelompok kontrol tidak berbeda nyata ( $p$-value $>$ 
0.05). Hasil penelitian ini relevan dengan penelitian sebelumnya yang menyatakan komik mampu meningkatkan pengetahuan tentang risiko penyakit (Montgomery et al., 2012; Mayo, 2011; Sakamoto et al., 2014; Tekle-Haimanot et al., 2016) dan perubahan sikap (Tekle-Haimanot et al., 2016; Branscum et al., 2013). Pernyataan ini juga diperkuat hasil penelitian Sakamoto et al. (2014) tentang fungsi manga sebagai alat pembelajaran efektif dalam meningkatkan pengetahuan dan kesadaran tentang tanda-tanda penyakit serta risiko kesehatan dengan disertai pembelajaran oleh guru pada siswa SD serta hasil penelitian Ohyama et al. (2015) dengan menggunakan media yang sama tetapi tanpa disertai dengan pembelajaran oleh guru pada siswa SMP.

Hasil penelitian ini juga mendukung pernyataan bahwa infografis yang memuat grafis lebih mudah dipahami sebagai penguat informasi risiko kesehatan dibandingkan informasi numerik (Zikmund-Fisher et al., 2007; Politi, 2012). Dengan demikian keseluruhan efek visual grafis tersebut sejalan dengan pendapat Chaffe (1987 dalam Rahmat 2003) tentang pengaruh visualisasi terhadap perubahan kognitif, afektif dan behavioral.

Menarik dan penting untuk diketahui dalam hasil penelitian ini adalah efek media visual berupa persepsi. Media visual yang berisi pesan positif mampu meningkatkan persepsi positif tentang manfaat dari gerakan pencegahan penyakit DBD sehingga Sismantik menyimpulkan risiko kesehatan menjadi rendah. Hasil tersebut relevan dengan premis Slovic et al. (2004 dalam Sheppard et al. 2012) yang menyatakan manfaat positif dari suatu kegiatan akan menyebabkan penerima pesan menyimpulkan risiko menjadi rendah. Namun, persentase peningkatan persepsi sebagai akibat pemberian media visual yang berisi pesan negatif masih pada kategori positif meskipun hasil pre-test dan post-test berbeda nyata.

\section{Efektifitas Media Visual}

Hasil analisis ANOVA Type III (Tabel 4) dapat diketahui perbedaan perlakuan (media visual) berpengaruh nyata terhadap pemahaman informasi, persepsi risiko dan sikap pencegahan terhadap penyakit DBD, ditunjukkan dengan nilai $p$-value $<$ $0.05(\alpha<0.05)$. Namun, perbedaan lokasi sekolah hanya berpengaruh nyata terhadap pemahaman informasi dan persepsi risiko tentang penyakit DBD, sedangkan terhadap sikap tidak berpengaruh nyata ( $p$-value $>0.05$ ).

Efektifitas media visual lebih lanjut dapat dilihat berdasarkan uji Duncan. Hasil uji Duncan (Tabel 5) pada sub peubah pemahaman informasi dengan menggabungkan data kedua sekolah dari dua kecamatan yang berbeda, maka diperoleh hasil antara kelompok perlakuan dengan kelompok kontrol berbeda nyata, ditunjukkan dengan simbol yang berbeda. Dalam penyampaian informasi, terlihat infografis manfaat positif memiliki rata-rata pemahaman informasi tertinggi (simbol A). Namun, hasilnya tidak berbeda nyata dengan infografis dan manga risiko penyakit, ditunjukkan dengan simbol yang sama (simbol A). Artinya, pemberian informasi tentang penyakit DBD dengan menggunakan ketiga media penyuluhan tersebut hasilnya akan sama saja. Selanjutnya, manga manfaat positif menghasilkan nilai rata-rata pemahaman informasi yang paling kecil dibandingkan dengan media lainnya. Hasil wawancara dapat diketahui bahwa informasi dalam infografis paling mudah untuk dipahami dan diingat karena memuat pesan yang singkat dan jelas. Namun, informasi dalam manga juga masih dapat dipahami karena ditampilkan dengan alur cerita meskipun tidak

Tabel 4. Hasil Analisis ANOVA Type III Peubah Efek Media Visual di Kedua Lokasi Tahun 2017

\section{Efek Media Visual}

\begin{tabular}{llccccccc}
\multirow{2}{*}{ No } & \multirow{2}{*}{ Sumber } & DF & \multicolumn{2}{c}{$\begin{array}{c}\text { Pemahaman } \\
\text { Informasi }\end{array}$} & \multicolumn{2}{c}{ Persepsi Risiko } & \multicolumn{2}{c}{ Sikap } \\
\cline { 3 - 9 } & & & Mean & p-value & Mean & p-value & Mean & p-value \\
\hline 1 & Kelompok & 4 & 793.10 & $<0.0001^{*}$ & 474.65 & $<0.0001^{*}$ & 1193.86 & $<0.0001^{*}$ \\
2 & Lokasi Sekolah & 1 & 245.61 & $0.0003^{*}$ & 1709.52 & $<0.0001^{*}$ & 17.62 & 0.4975 \\
\hline
\end{tabular}

Keterangan: * berbeda nyata pada $\alpha<0.05$ 
semudah menangkap informasi dalam infografis.

Berdasarkan perbandingan sekolah (Tabel 5) terlihat respon yang paling baik untuk pemahaman informasi diperoleh oleh MI Al Huda Cibinong yang berada di perkotaan (simbol A). Namun, jika dilihat nilai rata-ratanya tidak terlalu jauh berbeda dengan nilai rata-rata pemahaman informasi dari MI Nurul Qolbi Bojong Gede yang berada di pedesaan. Hasil yang berbeda nyata pada komponen sekolah diperkuat juga dengan hasil post-test di mana Sismantik MI Al Huda Cibinong memiliki nilai rata-rata lebih tinggi dibandingkan di MI Nurul Qolbi Bojong Gede. Hal ini ditujukan dengan persentase pada kategori tinggi yang lebih besar. Kondisi demikian disebabkan perbedaan karakteristik wilayah pada kedua sekolah tersebut. Wilayah perkotaan (Cibinong) yang identik dengan taraf kemajuan setingkat lebih tinggi daripada pedesaan (Bojong Gede) ditandai dengan kecepatan dan kemudahan akses informasi dan komunikasi sehingga beragam informasi dapat diperoleh dengan lengkap dan cepat.

Berdasarkan Tabel 5 dapat dilihat antara manga dan infografis risiko penyakit serta infografis manfaat positif tidak berbeda nyata pada sub peubah sikap, artinya tingkat pembentukan sikapnya relatif sama. Manga manfaat positif adalah media penyuluhan yang paling efektif dalam pembentukan sikap pencegahan penyakit DBD, ditunjukkan dengan simbol A dan nilai mean paling tinggi. Selain itu, keempat perlakuan berbeda nyata dengan kelompok kontrol yang artinya perlakuan media visual memberikan efek perubahan sikap pada Sismantik. Fakta di lapangan menunjukkan unsur naratif yang memuat emosi dan kesamaan usia pada karakter tokoh manga juga ikut mengarahkan perilaku kesehatan yang positif.

Uji perbandingan Duncan untuk sub peubah persepsi dengan skala yang sama digunakan untuk menilai tingkat kepositifan sehingga dapat diketahui mana yang menimbulkan efek positif atau negatif. Informasi positif cenderung akan menimbulkan anggapan bahwa penyakit DBD tidak terlalu berisiko asalkan dilakukan pencegahan dan hidup sehat sejak dini, sementara dengan pemberian informasi negatif akan menimbulkan anggapan bahwa penyakit DBD sangat bersiko/berbahaya. Hal ini ditunjukkan pada uji Duncan di mana semakin tinggi nilai rataannya maka semakin positif sedangkan semakin rendah rataaannya maka semakin rendah pula persepsi positifnya.

Berdasarkan uji Duncan sub peubah persepsi dengan skala sama di atas (tabel 5), maka diketahui bahwa manga dan infografis tentang manfaat positif dapat menimbulkan persepsi positif. Selanjutnya untuk pesan negatif tentang risiko DBD, perlakuan menggunakan manga nilai positifnya paling rendah,

Tabel 5. Hasil uji Duncan Peubah Efek Media Visual pada Kelompok Perlakuan dan Kontrol di Kedua Lokasi Tahun 2017

\begin{tabular}{|c|c|c|c|c|c|c|c|c|c|}
\hline \multirow{3}{*}{ No } & \multirow{3}{*}{ Perlakuan } & \multirow{3}{*}{$\mathbf{N}$} & \multicolumn{7}{|c|}{ Efek Media Visual } \\
\hline & & & \multicolumn{3}{|c|}{ Pemahaman Informasi } & \multicolumn{2}{|c|}{$\begin{array}{c}\text { Persepsi Risiko } \\
\text { (skala sama) }\end{array}$} & \multicolumn{2}{|c|}{ Sikap } \\
\hline & & & Mean & & ping & Mean & $\begin{array}{c}\text { Duncan } \\
\text { Grouping }\end{array}$ & Mean & $\begin{array}{l}\text { Duncan } \\
\text { Grouping }\end{array}$ \\
\hline 1 & Manga + & 60 & 26.67 & B & & 33.82 & A & 41.82 & $\mathrm{~A}$ \\
\hline 2 & Manga - & 57 & 27.33 & B & $\mathrm{A}$ & 26.81 & $\mathrm{C}$ & 39.20 & $\mathrm{~B}$ \\
\hline 3 & Infografis + & 60 & 28.70 & & $\mathrm{~A}$ & 32.52 & A & 39.42 & $\mathrm{~B}$ \\
\hline 4 & Infografis - & 57 & 27.61 & B & $\mathrm{A}$ & 29.33 & B & 39.37 & $\mathrm{~B}$ \\
\hline 5 & Kontrol & 57 & 19.47 & $\mathrm{C}$ & & 29.33 & $\mathrm{~B}$ & 30.07 & $\mathrm{C}$ \\
\hline 6 & Al Huda & 148 & 26.84 & \multicolumn{2}{|c|}{$\mathrm{A}$} & 32.76 & $\mathrm{~A}$ & 38.20 & $\mathrm{~A}$ \\
\hline 7 & Nurul Qolbi & 143 & 25.11 & \multicolumn{2}{|c|}{ B } & 28.00 & $\mathrm{~B}$ & 37.85 & A \\
\hline
\end{tabular}

Keterangan: Tingkat efektifitas tertinggi secara berurutan A, B, C dan jika simbolnya sama artinya tingkat efektifitasnya sama; manga + dan infografis + berisi pesan manfaat positif gerakan 3M; manga - dan infografis - berisi pesan risiko DBD 
artinya media tersebut dapat menimbulkan persepsi negatif. Namun, perlakuan dengan infografis risiko penyakit tidak akan berpengaruh terhadap persepsi negatif, ditunjukkan dengan simbol yang sama dengan kelompok kontrol (simbol C). Perbedaan sekolah juga berpengaruh terhadap persepsi risiko, ditunjukkan dengan simbol berbeda. Sismantik menyatakan bahwa alur cerita dalam manga menunjukkan realitas di lapangan sehingga mereka yakin terhadap kebenaran informasi yang disampaikan.

Tingkat efektifitas media untuk sub peubah persepsi risiko dapat dilihat dari skala berbeda. Hasil uji Duncan (Tabel 6) diperoleh data bahwa manga manfaat positif berbeda nyata dengan infografis positif, artinya manga lebih efektif dalam membentuk persepsi positif (simbol A) dibandingkan infografis (simbol B). Hal yang sama ditunjukkan oleh manga risiko penyakit berbeda nyata dengan infografis risiko penyakit, di mana nilai mean-nya lebih tinggi dibandingkan infografis risiko penyakit. Dengan demikian, manga merupakan media yang paling efektif membentuk persepsi baik positif dan negatif.

Uji Duncan dengan skala berbeda (Tabel 6) menunjukkan MI Nurul Qolbi Bojong Gede memiliki persepsi positif dan negatif paling tinggi, ditunjukkan dengan nilai mean yang lebih tinggi. Artinya, pemberian perlakuan baik manga maupun infografis mampu meningkatkan persepsi yang lebih tinggi di MI Nurul Qolbi jika dibandingkan MI Al Huda Cibinong. Fakta di lapangan menunjukkan bahwa Sismantik di MI Nurul Qolbi Bojong Gede lebih banyak dipengaruhi faktor lingkungan keluarga dan masyarakat dan relatif rendah dalam terpaan media sehingga tidak banyak informasi yang dapat mempengaruhi pola fikir mereka. Akibatnya, saat dilakukan perlakuan media visual, Sismantik di sekolah tersebut merasa lebih yakin terhadap informasi yang diberikan karena tidak banyak informasi lain tentang DBD yang diperoleh sehingga menyebabkan persepsi mereka baik bersifat positif dan negatif lebih tinggi dibandingkan di MI Al Huda Cibinong.

Mengacu pada data hasil analisis ANOVA Type III dan uji perbandingan Duncan pada kelompok perlakuan dan kelompok kontrol di kedua lokasi penelitian, maka media visual memiliki tingkat efektifitas yang berbeda untuk peubah pemahaman informasi, persepsi risiko dan sikap terhadap pencegahan DBD. Peningkatan persepsi positif dan negatif lebih efektif menggunakan manga sebagai media penyuluhan kesehatan risiko penyakit DBD dibandingkan infografis, sedangkan penggunaan infografis risiko penyakit hasilnya tidak akan menimbulkan perubahan pada persepsi negatif sasaran. Karakteristik sasaran yang memiliki persepsi awal yang bersifat positif menjadi alasan keberhasilan penggunaan media visual dalam meningkatkan persepsi positif. Hasil tersebut juga dapat dijelaskan dengan teori bahwa proses mental dalam kognisi visual yang mempengaruhi persepsi salah satunya adalah salience (Bloomer, 1990) di mana rangsangan akan dilihat "lebih" jika memiliki makna bagi individu. Unsur cerita (naratif) dan karakter dalam manga bermakna lebih bagi pembacanya sehingga mempengaruhi persepsi mereka. Berbeda dengan

Tabel 6. Hasil Uji Duncan Sub Peubah Persepsi Risiko tentang Penyakit DBD (Skala Tidak Sama) Pada Kelompok Perlakuan dan Kontrol di Kedua Lokasi Tahun 2017

\begin{tabular}{|c|c|c|c|c|c|}
\hline No & Perlakuan & $\mathbf{N}$ & Mean & \multicolumn{2}{|c|}{ Duncan Grouping } \\
\hline 1 & Manga + & 60 & 33.82 & & A \\
\hline 2 & Manga - & 57 & 33.20 & B & A \\
\hline 3 & Infografis + & 60 & 32.52 & B & $\mathrm{A}$ \\
\hline 4 & Infografis - & 57 & 30.67 & B & $\mathrm{C}$ \\
\hline 5 & Kontrol & 57 & 29.33 & & $\mathrm{C}$ \\
\hline 6 & MI Al Huda & 148 & 31.87 & & \\
\hline 7 & MI Nurul Qolbi & 143 & 32.00 & & \\
\hline
\end{tabular}

Keterangan: Tingkat efektifitas tertinggi secara berurutan A, B, C dan jika simbolnya sama artinya tingkat efektifitasnya sama; manga + dan infografis + berisi pesan manfaat positif gerakan 3M; manga - dan infografis - berisi pesan risiko DBD 
infografis yang hanya berupa deskripsi informatif singkat sehingga tidak berpengaruh pada persepsi risiko. Selanjutnya, media penyuluhan yang paling efektifdalam pembentukansikappencegahan terhadap penyakit DBD adalah manga manfaat positif. Manga yang memuat unsur narasi akan mengarahkan kepada efek persuasi yang lebih besar dan penurunan pikiran negatif (Leung, 2010), sehingga penyuluhan yang di dalamnya memuat pendidikan kesehatan dalam mengarahkan sikap positif lebih tepat menggunakan manga. Dengan demikian, pendapat Branscum dan Sharma (2009) bahwa komik manga merupakan alat pendidikan yang menjanjikan terutama di kalangan anak-anak adalah tepat.

Hasil analisis di atas relevan dengan penelitian sebelumnya dalam bidang komunikasi kesehatan yaitu citra visual dan grafis mampu meningkatkan pengetahuan kesehatan (McWhriter dan HoffmanGoetz, 2013), pemahaman tentang risiko penyakit (Lipkus dan Holland, 1999) dan meningkatkan kemampuan mengingat kembali (recall) informasi (Sullivan et al., 2016). Hal tersebut juga mendukung penelitian Tekle-Haimanot et al. (2016) dan Branscum et al. (2013) yang menyatakan komik memberikan efek perubahan terhadap peningkatan sikap.

\section{Kesimpulan}

Pemahaman awal Sismantik di kedua lokasi tentang penyakit DBD cukup baik, tetapi pemahaman awal Sismantik di MI Al Huda Cibinong lebih baik dibandingkan di MI Nurul Qolbi Bojong Gede. Persepsi negatif awal Sismantik yang menganggap penyakit DBD berisiko di MI Al Huda Cibinong lebih tinggi dibandingkan MI Nurul Qolbi Bojong Gede, sedangkan sikap awal pencegahan Sismantik terhadap penyakit DBD di MI Al Huda Cibinong lebih tinggi dibandingkan di MI Nurul Qolbi Bojong Gede.

Perlakuan media visual terbukti mampu memberikan efek berupa peningkatan pemahaman informasi, persepsi risiko dan sikap Sismantik terhadap pencegahan penyakit DBD. Namun, peningkatan persepsi negatif masih kecil, yang disebabkan persepsi awal bersifat positif dan anakanak sulit untuk diubah persepsi dalam waktu singkat kecuali dilaksanakan penyuluhan secara kontinu. Dengan demikian, manga dan infografis dapat menjadi media penyuluhan yang tepat bagi Sismantik dalam meningkatkan pemahaman informasi, persepsi risiko dan sikap.

Perlakuan manga dan infografis menghasilkan efektifitas yang berbeda. Media visual yang paling efektif sebagai sarana penyuluhan untuk meningkatkan persepsi risiko adalah manga (kedua jenis tipe pesan) dan manga manfaat positif untuk pembentukan sikap positif. Namun, media visual memiliki tingkat efektifitas yang sama baik manga maupun infografis dalam meningkatkan pemahaman informasi. Perbedaan lokasi sekolah juga ikut mempengaruhi pemahaman informasi dan persepsi risiko tentang penyakit $\mathrm{DBD}$, tetapi tidak berpengaruh terhadap sikap.

Berdasarkan kesimpulan di atas maka perlu dilaksanakan peningkatan penyuluhan kesehatan tentang pentingnya tindakan pencegahan penyakit DBD dengan Gerakan 3M Plus untuk mengeliminasi persepsi salah tentang fogging (pengasapan) yang dianggap sebagai satu-satunya cara paling efektif mengatasi penyakit DBD di masyarakat.

Penting memperhatikan upaya peningkatan partisipasi anak-anak setingkat Sekolah Dasar sebagai kader Sismantik melalui penyuluhan pentingnya peran stategis Sismantik sebagai upaya mencegah penyakit DBD. Selain itu, perlu perhatian dan upaya peningkatan penyuluhan kesehatan di sekolah di bawah naungan Kemenag (Madrasah Ibtidaiyah) oleh Dinas Kesehatan setempat dalam rangka meningkatkan derajat kesehatan masyarakat, mengingat jumlahnya cukup banyak sebagai bagian dari siswa setingkat Sekolah Dasar.

Dinas Kesehatan setempat sebaiknya mempertimbangkan untuk menggunakan media visual dalam penyuluhan kesehatan dengan pengkhususan pada media tertentu (manga) bagi anak-anak dalam mengarahkan persepsi dan sikap positif yang mendukung kesehatan. Selain itu, penting mempertimbangkan infografis sebagai media penyuluhan kesehatan yang bersifat informatif dalam keadaan risiko dari segi efisiensi dan efektifitas.

\section{Daftar Pustaka}

Ahmadi D, Sulaeman AI. 2009. Sikap Masyarakat terhadap Pemberitaan Bahaya Flu Babi di Media Massa. MIMBAR, 25(2) : 181-195.

Ancker JS, Senathirajah Y, Kukafka R, Starren JB. 2006. Design Features of Graphs in Health Risk Communication: A Systematic Review. Journal 
Am Med Inform Assoc, 13 (6) : 608-618.

Bloomer CM. 1990. Principles of Visual Perception. New York: Design Press.

Branscum P, Sharma M. 2009. Comic Books an Untapped Medium for Health Promotion. American Journal of Health Studies, 24(4) : 430439.

Branscum P, Sarma M, Lang LW, Wilson B, Rojas L. 2013. A true challenge for any superhero an evaluation of comic book obesity prevention program). Fam Community Health Journal, 36(1) :63-76.

Cummings CL. 2013. Impacts of Communicating Secondary Risks on Risk Reduction Responses: The Case of Nanoparticle-Formulated Sunscreen. [Disertasi]. US: North Carolina State University.

[Depkes RI] Departemen Kesehatan RI. 2009. Profil Kesehatan Indonesia. Jakarta (ID): Departemen Kesehatan RI.

[Dinkes Kab Bogor] Dinas Kesehatan Kabupaten Bogor. 2015. Profil Dinas Kesehatan Kabupaten Bogor. Cibinong (ID): Dinkes Kab Bogor.

Dur BIU, Filipczak-Bialkowska A, Bresciani S, Ge J, Niu Y, Othman A, Wils D. 2014. Interactive Infographics on the Internet. In International Conference on Communication, Media, Technology and Design. Department of Visual Communication Design, TOBB University of Economics and Technology.

Edgar T, Volkman JE. 2012. Using Communication Theory for Health Promotion: Practical Guidance on Message Design and Strategy. Health Promotion Practice, 13(5) : $587-590$.

Furuno Y, Sasajima H. 2015. Medical Comics as Tools to Aid in Obtaining Informed Consent for Stroke Care. Journal Medicine, 94 (26) : 1-4.

Garcia-Retamero R, Galesic M. 2010. Who Proficts From Visual Aids: Overcoming Challenges in People's Understanding of Risks. Social Science And Medicine, 70(7) : 1019-1025.

Garcia-Retamero R, Mandeep KD. 2011. Pictures Speak Louder than Numbers: On Communicating Medical Risks to Immigrants with Limited Nonnative Language Proficiency. Health Expectations, $14(1): 46-57$

Hamdan SR. 2015. Pengaruh Peringatan Bahaya Rokok Bergambar pada Intensi Berhenti Merokok. MIMBAR, 31(1) : 241-250.

Hecht ML, Miller-Day M. 2007. The Drug Resistance
Strategies Project as Translational Research. Journal of Applied Communication Research, 35(4) : 343-349.

Jayawardene WP, Lohrmann DK, Youssefagha AHC, Nilwala DC. 2011. Prevention of Dengue Fever: An Exploratory School-Community Intervention Involving Students Empowered as Change Agents. Journal School Health, 81(9) : 566-573.

King A, Jensen JD, Davis LSA, Carcioppolo N. 2014. Perceived Visual Informativeness (PVI): Construct and Scale Development to Assess Visual Information in Printed Materials. Journal of Health Communication, 19(10) : 1099-1115.

[Kemenkes RI] Kementrian Kesehatan Republik Indonesia. 2014. Petunjuk Teknis Jumantik-PSN Anak Sekolah. Jakarta (ID): Kemenkes RI.

Kreuter MW, Green MC, Cappella JN, Slater MD, Wise ME, Storey D, Woolley S. 2007. Narrative communication in cancer prevention and control: a framework to guide research and application. Annals of Behavioral Medicine, 33(3) : 221-235.

Leung MM. 2010. Fight for Your Right to Fruit: Development and Testing of a Manga Comic Promoting Fruit Intake in Middle-School Youth. [disertasi]. Chapel Hill: University of North Carolina.

Leung MM, Tripicchio G, Agaronov A, Hou N. 2014. Manga Comic Influences Snack Selection in Black and Hispanic New York City Youth. Journal of Nutrition Education and Behavior, 46(1) : 1-6.

Lipkus MI, Holland JG. 1999. The Visual Communication of Risk. Journal of the National Cancer Institute Monographs, 25 : 149-163.

Matsuoka R, Smith I, Uchimura M. 2011. Discourse Analysis of Encouragement in Healthcare Manga. Journal of Pan-Pacific Association of Applied Linguistics, 15(1) : 49-66.

Mayo C. 2011. Use of a Popular Comic Strip Character as a Teaching Tool in Aphasia: The Case for "Grandpa Jim". Perspectives on Issues in Higher Education, 14(2) : 46-56.

McWhirter JE, Hoffman-Goetz L. 2014. A Systematic Review of Visual Image Theory, Assessment, and Use in Skin Cancer and Tanning Research. Journal of Health Communication, 19(6) : 738-757.

Miller BM, Barnett B. 2010. Understanding of Health Risks Aided by Graphics with Text. Newspaper Research Journal, 31(1) : 52-68.

Montgomery M, Manuelito B, Nass CT, Dedra B. 
2012. The Native Comic Book Project: Native Youth Making Comics and Healthy Decisions. Journal Cancer Education, 27(10) : 41- 46.

Mutonyi H, Kendrick M. 2011. Cartoon Drawing as a Means of Accessing what Students Know about HIV/AIDS: An Alternative Method. Visual Communication, 10(2) : 231-249.

Notoatmodjo S. 2005. Ilmu Promosi Kesehatan. Jakarta (ID): Rineka Cipta.

Notoatmodjo S. 2010. Promosi Kesehatan dan Ilmu Perilaku. Jakarta (ID): Rineka Cipta.

Ohyama S, Yokota C, Miyashita F, Amano T, Inoue Y, Shigehatake Y, Sakamoto Y, Toyoda K, Minematsu K. 2015. Effective Education Materials to Advance Stroke Awareness without Teacher Participation in Junior High School Students. Journal of Stroke and Cerebrovascular Diseases, 24(11) : 2533-2538.

Politi MC. 2012. Numbers Can Be Worth a Thousand Pictures: Individual Differences in Understanding Graphical and Numerical Representations of Health-Related Information. Health Psychology, 31(3) : 286-296.

PKP Kemenkes RI. 2015. Demam Berdarah Biasanya Mulai Meningkat di Bulan Januari. [internet]. dapat diunduh di http://www.depkes.go.id/ article/view/15011700003/.

Quintiliani LM, Carbone ET. 2005. Impact of DietRelated Cancer Prevention Messages Written with Cognitive and Affective Arguments on Message Characteristics, Stage of change, and Self-Efficacy. Journal of Nutrition Education and Behavior, 37(1) : 12-19.

Rahayu RD, Wigna W. 2010. Pengaruh Lingkungan Keluarga, Sekolah dan Masyarakat terhadap Persepsi Gender Mahasiswa Laki-Laki dan Perempuan (Kasus Mahasiswa Sekolah Tinggi Ekonomi Islam TAZKIA Tahun Masuk 2009). Jurnal Penyuluhan, 6(2) : 1-23.

Rahmat J. 2003. Psikologi Komunikasi. Bandung (ID): PT Remaja Rosdakarya.

Ru G, Ming Z. 2014. Infographics Applied in Design Education. IEEE Workshop on Advanced Research and Technology in Industry Applications (WARTIA), 1 : 984-986.

Sakamoto Y, Yokota C, Miyashita F, Amano T, Shigehatake Y, Oyama S, Itagaki N,. Okumura K, Toyoda K, Minematsu K. 2014. Effects of Stroke Education Using an Animated Cartoon and a
Manga on Elementary School Children. Journal of Stroke and Cerebrovascular Diseases, 23(7) : 1877-1881.

Serchay DS. 2008. The Librarian's Guide to Graphic Novels for Children and Teens. 1st ed. New York: Neal-Schuman Publishers Inc.

Sheppard B, Janoske M, Liu, B. 2012. Understanding Risk Communication Theory: A Guide for Emergency Managers and Communicators. Department of Homeland Security (START).

Stone ER, Gabard AR, Groves AE, Lipkus IM. 2015. Effects of numerical versus foreground-only icon displays on understanding of risk magnitudes. Journal of Health Communication, 20(10) : 1230-1241.

Sullivan WH, O’Donoghue AC, Aikin KJ, Chowdhury D, Moultrie RR, Rupert DJ. 2016. Visual Presentations of Efficacy Data in Direct-toConsumer Prescription Drug Print and Television Advertisements: A Randomized Study. Journal Patient Education and Counseling, 99(5) : 790799.

Tekle-Haimanot R, Pierre-Marie P, Daniel G, Worku, Dawit K, Belay, Hanna D, Gebrewold, Meron A. 2016. Impact of an Educational Comic Book on Epilepsy-Related Knowledge, Awareness, and Attitudes among School Children in Ethiopia. Epilepsy and Behavior, 61(2016) : 218-223.

Viadero D. 2009. Scholars See Comics as no Laughing Matter. Educ Week, 28(21) :1-11.

Wakane H, Watanabe S, Takeshita N. 2007. Isha/ Iryo-Manga ni Mirareru Kitsuen Byoshabamen Nitsuiteno Chosa. (Study on Scenes of Smoking in Healthcare Comic Books). Nihon Ijishinpo (Japan Medical Journal), 4358: 81-83.

Wong ST, Pe'rez-Stable EJ, Kim SE, Gregorich SE, Sawaya GF, Walsh JME, Washington AE, Kaplan CP. 2012. Using Visual Displays to Communicate Risk of Cancer to Women from Diverse Race/ Ethnic Backgrounds. Patient Education and Counseling, 87(3) : 327-335.

Zikmund-Fisher BJ, Ubel PA, Smith DM, Derry HA, McClure JB, Stark A, Pitsch RK, Fagerlin A. 2008. Communicating Side Effect Risks in a Tamoxifen Prophylaxis Decision Aid: The Debiasing Influence of Pictographs. Patient Education and Counseling, 73(2) : 209-214. 